DOI: $10.17805 /$ trudy.2017.3.7

ИСТОРИЯ

\title{
ЛОМОНОСОВСКИЙ ПОРЫВ: ИСТОРИЯ КАК ФИЛОСОФИЯ, ИСКУССТВО, ПОЭЗИЯ
}

\author{
О. Г. Жукова \\ Московский гуманитарный университет
}

Аннотация: Рецензия на издание: Васильев Ю.А. М. В. Ломоносов в русской исторической школе. М. : Изд-во Моск. гуманит. ун-та, 2016. - 168 с.

Ключевые слова: рецензия; М. В. Ломоносов; русская историческая школа; история; историческое знание; историософия; исторический процесс; история России

\section{LOMONOSOV'S IMPULSE: HISTORY AS PHILOSOPHY, ART, POETRY}

\author{
O. G. Zhukova \\ Moscow University for the Humanities
}

\begin{abstract}
A review of the publication: Vasiliev Y.A., M. V.Lomonosov in the Rus-sian historical school. Moscow: Moscow University for the Humanites Publ. 2016. - 168 p.

Keywords: review; M. V. Lomonosov; Russian historical school; history; historical knowledge; historiosophy; historical process; history of Russia
\end{abstract}

Издательство Московского гуманитарного университета опубликовало новую книгу доктора исторических наук, профессора кафедры истории Московского гуманитарного университета Ю. А. Васильева о М. В. Ломоносове (Васильев, 2016). Примечательно, что предыдущее издание автора о другой значимой персоне отечественной истории другой исторической эпохи - Ю. В. Андропове, увидевшее свет также в этом же издательстве, получило широкий общественный резонанс в России, а также за рубежом (см.: Васильев, 2014b; текст есть в свободном доступе в базе НЭБ).

Понимание, что Михаил Васильевич Ломоносов - «наше все» приходит к нам, россиянам, еще в школьные годы. Глядя на портрет ученого в кабинете истории, мы узнавали, что автор «Истории Российской» считал главной своей задачей «очистить исторические корни» нашего народа. Борясь с последователями «норманнской теории», доказал, что вовсе не от шведов ведем мы свой корень, но ошибался, считая скифов предками россиян. И во многом опередили время и даже предопределили будущее высказанные им мысли в трактате-письме «О размножении и сохранении 
народа российского», а иллюстрация из учебника - мозаика «Полтавская баталия», выполненная из смальты ломоносовского производства, довершала впечатление о великом энциклопедисте, по истине широко распространившем «руки свои в дела человеческие».

Монография Юрия Альбертовича Васильева «М. В. Ломоносов в русской исторической школе» открывает нам Михаила Васильевича с неожиданных сторон. «Его интеллектуальное и творческое наследие стоит особняком, не вписываясь ни в какие идеологемы и традиционные форматы» (Васильев, 2016: 3) - заявляет профессор Васильев в предисловии к своей монографии и доказывает эту мысль всем своим исследованием. Новаторский характер его книги проявляется в том, что наследие М. В. Ломоносова рассматривается и оценивается в контексте идей, разработанных в русской исторической школе, теоретические построения которой представляют оригинальную методологию, основанную на авторской системе теоретико-методологических и историософских воззрений, нередко опережавших соответствующий уровень истории интеллектуальной мысли мыслителей Запада.

Основы историософской традиции в России, хронологически более ранней, проявились в исторических идеях М. В. Ломоносова. Историософский подход противопоставлял исторической эмпиричности выявление смысловых значений в событийности исторического процесса, восприятие истории как телеологического явления. По оценке автора, наследие М.В. Ломоносова в российском историописании можно по достоинству оценить лишь с учетом историософской парадигмы. В исторических построениях Ломоносова закладывались основы историософской традиции России. Именно в таком ключе следует расценивать идеи мыслителя как передовые для исторического знания России середины и второй половины XVIII в. Наследие Ломоносова стало интеллектуальной основой для последующего становления исторической науки в России (Васильев, 2016: 133).

Теоретико-методологический подход, сформированный русской исторической школой хронологически позднее, во второй половине XIX - начале XX века, воспринял целый ряд ломоносовских исторических идей. Русская историческая школа обогатила мировую интеллектуальную мысль разработкой научной теории истории, включая комплекс онтологических, эпистемологических, аксиологических проблем истории (см.: Васильев, 2009ab, 2010ab, 2011ab, 2012b, 2014a). Особенность теории истории той эпохи интеллектуальной бифуркации заключалась в синкретичности историографической, философско-исторической, социологической, психологической проблематики. Другой новацией автора монографии о Ломоносове является постановка вопроса о конструктивной рецепции исторических идей между русской исторической школой и не- 
мецкими школами историков XVIII - XIX вв. (см.: Васильев, 2015а, 2016а; Васильев, Васильева, 2014).

Автор убеждает, что в ломоносовской парадигме история воспринимается не сухим перечислением событий прошлого, но как философия, искусство и даже поэзия. Выходит, что об историке, философе и поэте Ломоносове можно говорить уже как об историософе, рассматривать его творческое наследие в этой области как чрезвычайно актуальное для современности, вернувшейся, наконец, к синтезу наук, открывающей далекие перспективы исследований «на стыке» разных научных направлений.

Идейное наследие великого русского энциклопедиста важно для нас сегодня еще и тем, что не боялся он выходить на, как сказали бы мы современным языком, геополитические обобщения, отводя нам, россиянам, достойное место в истории человечества, понимая, как важна национальная история в формировании национального мировоззрения, самоуважения народа.

В своих изысканиях на эту тему Михаил Васильевич шел в фарватере мировых историософских течений. Его коллеги на Западе также уделяли огромное внимание этим аспектам бытия народов. Но много ли мы знаем об этом сегодня? Глубокую информационную лакуну, со ссылками на зарубежных ученых, современников Михаила Васильевича, заполняет профессор Васильев: «Уже в XVIII в. признавалось, что нации, у которых нет ни истории, ни историографии, коснеют в понятиях, перешедших к ним по преданию и установленных обычаем. Складывалось представление, что в национальной истории факты требовалось рассматривать в контексте мировой истории, с общечеловеческой точки зрения. По оценке немецкого историка Георга Гервинуса, это позволило выбрать и «очистить» материал: выделить все существенное, отбросить случайное. В результате появлялись основания и возможности для написания национальной истории по историческим идеалам, позволяющим изобразить национальный характер в его развитии (см.: Автобиография Гервинуса, 1893: 334, 336-337).

Продолжая своеобразный обзор и анализ взглядов зарубежных коллег Ломоносова на историю, профессор Васильев отмечает: «характерной чертой всех без исключения национальных историй европейских стран являлась синкретичность повествований с мифами. История народов приукрашивалась в сказаниях, становилась выражением тех идеалов, к которым устремлен дух народа. Немецкий теоретик истории XIX в. Иоганн Дройзен называл историю областью нравственных наук. По его оценке, «греки нарисовали себе чудесную, гармоничную картину своего прошлого - с тем, что от нее сохранилось действительно подлинного, она, к великому сожалению, совпадает мало» (Дройзен, 2004: 446). В классиче- 
ской Античности господствовало представление, что история относится к области риторики. Римская история также воспринималась частью риторики, художественной литературы. В XVIII в. это представление вновь возродилось в тезисе, что история является одновременно и наукой, и искусством» (Васильев, 2016: 4).

Таким образом, по заключению профессора Васильева, до конца XVIII - начала XIX в. история рассматривалась как часть художественной прозы. И только в это время в университетах Германии были предприняты попытки выделить историю в самостоятельную науку: «С этой поры историческая наука заменила поэтическое искусство и достигла важного значения для европейской цивилизации» (там же).

Людям XXI века, в большинстве своем черпающим «познания» об истории из дешевой беллетристики и псевдоисторических телесериалов, нетрудно представить времена господства тезиса «история есть одновременно и искусство, и наука. Читающая публика считала предпочтительнее первое. В результате историческая литература больше соответствовала популярной потребности. Многие великие поэты углубились в вопросы исторического познания. Риторическое искусство превращало тяжесть событий, трудных конфликтов, в условиях которых зарождались и разворачивались великие события, ужасы разгоревшихся страстей или жестоких притеснений, в художественный, отретушированный образ, в увлекательное чтение, производящее сильное впечатление. Однако, как подчеркивал И. Г. Дройзен, «есть другая задача, кроме как развлекать, поучая, и поучать, развлекая» (Дройзен, 2004: 566). Но тогдашней публике это направление истории было не по нраву: она хотела читать, а не изучать. Она жаловалась, что ей подают не яства, а рецепт их приготовления (см. там же: 565).

К сожалению, следует констатировать, что представления широкой публики о предназначении истории не изменились и по наши дни. А историческая грамотность публики столь низка, что не может она заметить в историческом контексте, например, сериала о событиях царствования Ивана III невозможных для того времени слов: шантаж, шарм, банда, инженер и выражения типа: «Надо решать вопрос». Также нелепо «слышатся» слова: «В комсомол сейчас вступает самая продвинутая молодежь» в сериале о 30-х годах прошлого века.

Но, как свидетельствует профессор Васильев, русская историческая школа имела опыт преодоления разрыва между историческим знанием и общественным сознанием во времена, не знавшие кино, телевидения и интернета (см.: Васильев, 2006, 2012a, 2015b, 2016b). Автор предлагает именно в этом русле рассматривать просветительский проект М. В. Ломоносова, предложившиго познавать историю с помощью изобразительно- 
го искусства, создавая произведения на исторические сюжеты, становившиеся своеобразными наглядными пособиями. Именно в этом контексте следует рассматривать и заботы Ломоносова о мозаичной мастерской, результатом которой стала знаменитая монументальная мозаика «Полтавская битва».

Важным и даже модным в современной историографии стала борьба с мифами и фальсификациями истории. Как помним, тема эта была близка и М. В. Ломоносову, неистово боровшемуся против историковмифотворцев своего времени. Обращаясь к прошлому и ссылаясь на мнение Ф. Анкерсмита, профессор Васильев приходит к неожиданному выводу: «в истории любой цивилизации существует неотъемлемая часть мифологизированного прошлого, которое она не может историзировать (т.е. сделать фактом истории), но которое в значительной мере определяет ее идентичность - иногда даже в большей степени, чем историзированное прошлое. В общественном сознании на определенных этапах развития проявляется стремление историзировать мифы своей истории, однако нередко вместо историзации мифов происходит историзирование только способа обращения с существующими мифами. <...> Мифологическое прошлое нельзя историзировать само по себе, поскольку это диссоциированное прошлое, недоступное даже для самых основательных попыток историзации, находящееся за пределами исторического времени. Оно пользуется высочайшим почетом: это есть историческое возвышенное цивилизации» (см.: Анкерсмит, 2007: 501, 503). Без постижения возвышенного исторического опыта невозможно определить идентичность народа, государства, нации (Васильев, 2016: 6).

Пожалуй, «высокий штиль» М. В. Ломоносова, коим писал он не только высокоторжественные оды, но и свои исторические работы, как нельзя лучше отвечает этому возвышенному историческому опыту, историософски определяющему место народа в истории цивилизаций.

Обращаясь к истокам зарождения историософии, профессор Васильев апеллирует к философскому учению Аристотеля и влияния его на школу Христиана Вольфа, утверждая, что: «вольфианству был близок рационализм философского учения Аристотеля, в аристотелевской теории чувственного восприятия познание мира являлось результатом взаимодействия с миром, воплощенного в опыте. Поэтому происходило не опровержение аристотелизма, а наоборот, включение в структуру вольфианства с учетом приспособления его к потребностям своего времени» (Васильев, 2016: 7). И именно на философии Вольфа и его последователей был воспитан М. В. Ломоносов в стенах высших духовно-академических учебных заведений России (Киевской и Московской академий).

В московской Славяно-греко-латинской и Киево-Могилянской ака- 
демиях аристотелизм «был первой формой европеизации русской общественной мысли и имел значимую роль». А вольфианство, сохраняя преемственную связь с аристотелизмом, сыграло значительную роль в европеизации русской общественной мысли XVIII в., позволив «русским интеллектуалам войти в атмосферу передовой в Западной Европе философской системы докантовской эпохи» (см.: Христиан Вольф..., 2001; Васильева, 2013, 2015a,b).

Такова была «образовательная ситуация», взрастившая ученогоэнциклопедиста Михаила Васильевича Ломоносова, заложившая «фундаментальные черты мышления» русского гения. Хотя в советские времена этого не принято было признавать, ссылаясь на мнение Плеханова, о том, что в русском поморе «было слишком много самостоятельности для того, чтобы он без критики подчинился чьему-нибудь влиянию» (М. В. Ломоносов: pro et contra...2011: 591). Тогда же существовало мнение, что Ломоносов, оставаясь редким самородком русского мира, был отдален от мировой научной мысли, существовал в некоем вакууме и сам был неизвестен на Западе. Профессор Васильев находит в его историософской парадигме влияние идей многих великих ученых с мировым именем: Р. Декарта, Исаака Ньютона, Пьера Гассенди, Г. Лейбница. Ломоносовым были изучены славянские, византийские, греческие, прибалтийские источники, материалы по истории готов, венедов, аланов. Он был знаком с трудами античных авторов: Геродота, Страбона, Клавдия Птолемея, Тита Ливия, Корнелия Непота, Плиния Гая Секунда Старшего, Публия Корнелия Тацита, Квинта Курция Руфа, Луция Аннея Флора, Гая Юлия Солина. И средневековых авторов: Прокопия Кесарийского, Иорнанда (Иордана), Георгия Аматрола, Константина VII Багрянородного и др. Да и могло ли быть иначе, если Михаил Васильевич получил образование в Германии, свободно владел многими языками, включая, естественно, латынь «язык ученых», вел активную переписку с зарубежными коллегами?

Но важным для нас, людей XXI века, становится актуальная и в наше время «потребность сделать из истории похвальное слово русскому народу: история «дает государям примеры правления, подданным - повиновения, воинам - мужества, судиям - правосудия, младым - старых разум, престарелым - сугубую твердость в советах, каждому незлобивое увеселение, с несказанною пользою соединенное. Когда вымышленные повествования производят движения в сердцах человеческих, то правдивая ли история побуждать к похвальным делам не имеет силы, особливо ж та, которая изображает дела праотцев наших?» (Ломоносов, 1986b: 50). Автор монографии уверен: «Ломоносов был ярким патриотом своего Отечества, утверждавшим величие и славу своей Родины. Это был патриотизм национальный, народный, но не лубочно-имперский. В ломоно- 
совском патриотизме проявились качества поморского характера и духа как неповторимый тип русского человека, в становлении мировоззрения которого природные основания - лес и вода явились определяющими началами родного мироздания, дополненные отсутствием ментальных архетипов крепостного права и монголо-татарского ига. Таково авторское восприятие образа Ломоносова, основанное на личном отношении к истокам идентичности собственного архангелогородского рода» (Васильев, 2016: 33).

Ю. А. Васильев вносит важное уточнение, утверждая, что Ломоносов, частично воспринявший идеи Вольфа, вернулся из Германии в Петербург «квалифицированным современным исследователем. Занимаясь переводом и изложением Вольфа на русский язык, Ломоносов представил характеристику значимости вольфианской философии на общем фоне господствовавшего в России аристотелизма. По его оценке, все науки, «а особливо философия, не меньше от слепого прилепления ко мнениям славного человека, нежели от тогдашних неспокойств претерпели. Все, которые в оной упражнялись, одному Аристотелю последовали, и его мнения за неложные почитали» (Из Волфианской Експериментальной физики. Предисловие М. В. Ломоносова, 1986а: 272). Отдавая должное идеям «сего славного и в свое время отменитого от других философа», Ломоносов подчеркивал: «но тем не без сожаления удивляюсь, которые про смертного человека думали, будто бы он в своих мнениях не имел никакого погрешения, что было главным препятствием к приращению философии и прочих наук, которые от ней много зависят. Чрез сие отнято было благородное рвение, чтобы в науках упражняющиеся один перед другим старались о новых и полезных изобретениях» (там же: 273).

По мнению Ю. А. Васильева, «у Вольфа Ломоносов перенял восприятие знания, основанное на фундаменте философской мысли. Как и у Вольфа, для его взглядов характерен синтез рациональных и чувственных моментов познания. Воспринятое вольфианой аристотелианское взаимодействие между прошлым и его исследователем являлось основополагающим для исторического опыта Ломоносова. Продолжение вольфовских идей можно увидеть в ломоносовском разделении телесных и душевных свойств человека. К телесным дарованиям он относил возраст, век, пол, силу, красоту, здравие, проворность, а также чувства: зрение, слышание, обоняние, вкушение, осязание. В перечень одушевленных вещей включались, во-первых, душевные дарования: понятие, память, остроумие, воображение, рассуждение, произволение. Второй составляющей являлись страсти: радость и печаль, удовольствие и раскаяние, честь и стыд, надежда и боязнь, упование и отчаяние, гнев и милосердие, любовь и ненависть, удивление и гнушание, желание и отвращение. Третьей частью 
выступали добродетели: мудрость, благочестие, воздержание, чистота, милость, благо-дарность, великодушие, терпение, праводушие, незлобие, простосердечие, искренность, постоянство, трудолюбие, дружелюбие, послушание, скромность. Помимо положительных, в число душевных дарований Ломоносов относил также негативные - пороки: безумие, нечестие, роскошь, нечистоту, лю-тость, скупость, неблагодарность, гордость, малодушие, нетерпеливость, лукавство, злобу, лицемерие, дерзость, непостоянство, леность, сварливость, упрямство, грубость, самохвальство. В качестве внешнего состояния определялись благородие и неблагородие, счастье и несчастие, богатство и убожество, слава и бесславие, власть и безвластие, вольность и порабощение (см.: Ломоносов, 2007: 556, 559).

Какой яркий, сочный, глубокий психологический портрет любой исторической личности можно написать, следуя этой развернутой Ломоносовской схеме из полузабытых исконно русских слов-определений характера человеческого! Ее бы взять на вооружение современным историкам и беллетристам, подчас довольно сухо и поверхностно представляющим героев своих исторических повествований.

А еще, оказывается, Михаил Васильевич опередил интеллектуальную мысль современности, широко применяя в своих исследованиях метод гипотезы, который по словам немецкого историка XIX в. И. Г. Дройзена, компенсирует недостаток исторического знания. Для Ломоносова гипотезы «представляют собой единственный путь, которым величайшие люди дошли до открытия самых важных истин. Это - нечто вроде порыва, который делает их способными достигнуть знаний...» (Ломоносов, 1986a: 217).

И неудивительно, что этот «Ломоновский порыв» поддержал великий немецкий математик Леонард Эйлер, писавший советнику академической канцелярии И.Д. Шумахеру о склонности Ломоносова к теоретическим познаниям: «Ныне таковые умы весьма редки, так как большая часть остаются только при опытах, почему и не желают пускаться в рассуждения <...> Поэтому догадки г[осподина] Ломоносова тем большую имеют цену, что они удачно задуманы и вероподобны. Отсюда вовсе не следует, чтобы они были вполне доказаны, потому что дальнейшие исследования - согласуются ли они с истиною или нет - приведут нас к желанной цели <...> Догадок своих сам г[осподин] автор не выдает за конечные истины...» (Михаил Ломоносов глазами современников, 2011: 198-199).

Следует лишь добавить, что смелые гипотезы выдвигал Михаил Васильевич не только в области естественных и точных наук, близких Эйлеру, но и в области истории. И сам по-дружески признавался в письме Леонарду Эйлеру: «Я часто за самой работой ловил себя на том, что душой я блуждаю в древностях Российских» (Михаил Васильевич Ломоносов. 
Переписка, 2010: 245). И тут Михаил Васильевич снова опережает время, предугадывая заманчивую идею писателей-фантастов далекого будущего, обосновывающих с точки зрения науки саму возможность существования машины времени и временных порталов, благодаря которым когданибудь (как знать наверняка?) человечество сможет «блуждать» не только душой, но и телом в прошедших временах...

Профессор Васильев считает, что и сам историософский подход Ломоносова также опередил состояние интеллектуального знания своего времени и проявился в его основном историческом труде - «Древней Российской истории от начала российского народа до кончины великого князя Ярослава Первого», опубликованной в октябре 1766 г.

Эта работа, ставшая первой печатной отечественной монографией по истории России, была издана тиражом 2425 экз. - огромным по меркам своего времени, а в 1760-70-е гг. появились ее издания на немецком, французском и итальянском языках. Рецензии на нее во множестве опубликованы в европейской печати. Это ли не признание Ломоносова западным научном миром?

Но изучение творческого наследия М.В. Ломоносова приводит автора к мысли, что не только сам Михаил Васильевич пользовался заслуженным уважением коллег, но и сама российская история, благодаря его стараниям, становится в один ряд с национальными историями других ведущих стран мира. Так, например, «Краткий российский летописец с родословием» наглядно представляет отношения династии Рюриковичей с дворами европейских стран. И, как утверждает профессор Васильев: «Данный труд важен как презентация историософской идеи - показать политическое значение Руси в общеевропейской истории, включение российской истории в контекст мировой истории. Следует подчеркнуть, что «Краткий российский летописец с родословием» был напечатан несколькими выпусками большим тиражом: в июне 1760 г. - 1200 экз., в ноябре 1760 г. 2457 экз., допечатка в апреле 1761 г. - 2406 экз., то есть его общий тираж составил более 6 тыс. экз.! Вскоре появились его переводные издания на немецком и английском языках» (Васильев, 2016: 30).

Подтверждение горячего нрава русского энциклопедиста неожиданно находится даже среди книг его личной библиотеки - первый том «первоначальной» редакции «Истории Российской» Татищева пестрит резкими комментариями на полях: «о глупость!», «ложь на Плиния», «врешь, дурак» или просто «дурак», «неправда» и др. (см.: Библиотека М. В. Ломоносова..., 2010: 45). Сам же неистовый борец за «строгое и правильное разыскание истины» главным критерием в работе историка считал фактическую точность описаний исторических событий, строгий отбор фактов, их непредвзятую оценку, определение смысла явлений. 
Современной России, вновь спорящей о необходимости выработки государственной идеологии, должна пригодится ломоносовская парадигма, подразумевающая телеологический метод в разработке истории. Профессор Васильев акцентирует внимание на том, что этот аспект творчества М.В. Ломоносова «как правило, оценивается односторонне и подменяется проявлением патриотизма (в различных вариациях, в зависимости от политических и идеологических взглядов авторов: от «горячего» или «глубочайшего» патриота до «националиста»). Однако далеко не все так просто. В исторических концептах Ломоносова превалирует телеологизм вольфовского направления. Государственное могущество, в ломоносовском понимании, происходит из трех источников: первое основание связано с внутренней стабильностью, безопасностью и поддержкой подданных, второе определяется военной мощью, а также благоприятной ситуацией мира и выгодных отношений с соседями, третий источник могущества государства основан на внешней торговле. Российская империя по данным критериям, предложенным Ломоносовым, рассматривалась им на равном уровне с лучшими европейскими странами, а многие превосходила» (Васильев, 2016: 33).

Важнейшим вкладом в отечественную историческую науку стала предложенная Ломоносовым периодизация русской истории, заложившая основу русской хронологии. Первым из российских историков Ломоносов стал рассматривать историю Отечества в контексте других национальных историй, смог «осуществить сравнительное ее сопоставление с историей других великих народов» (Васильев, 2016: 34). Т. е. пришел к пониманию необходимости синхронного изучения истории. Как уверял историк графа И. И. Шувалова о результатах своей работы: «древность Российского народа и славные дела наших Государей свету откроются» (Михаил Васильевич Ломоносов. Переписка, 2010: 169).

Цикличность истории, о которой стали говорить ученые более позднего времени, так же была предугадана Ломоносовым, утверждавшим телеологическую установку, что «народ российский» с времен глубокой древности «высочайшей степени величества, могущества и славы достигнул. <...> Каждому несчастию последовало благополучие, большее прежнего, каждому упадку высшее восстановление». Как отмечает профессор Васильев: «Идея Ломоносова констатировала наличие цикличности в историческом процессе. Объяснение подобных успехов, в духе вольфовской теории, сводилось к божественному промыслу, благодаря которому «воздвигнуты были бодрые государи» (Ломоносов, 1986b: 48). В этой связи показательна ломоносовская ассоциация исторического процесса с образом течения великой реки, «которая, от источников своих по широким полям распростираясь, иногда в малые потоки разделяется и между мно- 
гими островами теряет глубину и стремление; но, паки соединясь в одни береги, вящую быстрину и великость приобретает; потом присовокупив в себя иные великие от сторон реки, чем далее протекает, тем обильнейшими водами разливается и течением умножает свои силы (там же). Подобное онтологическое восприятие истории как временного потока человеческого бытия у Ломоносова. По оценке Ю. А. Васильева, разделялось от осознания и переживания людьми данного процесса, что составляло историческое познание» (Васильев, 2016: 34).

Интереснейшим аспектом для вдумчивого читателя монографии Ю. А. Васильева становятся его размышления о причинах критики воззрений Ломоносова такими крупными российскими историками, как С. М. Соловьев и В. О. Ключевский, идеологом марксизма Г. В. Плехановым с позиций своего исторического времени. А так же критика самого Ломоносова, направленная на коллег-современников - Г. Ф. Миллера, Г. З. Байера, А. Л. Шлецера.

Сегодня имена этих российских ученых немецкого происхождения известны широкой публике именно потому, что яростно критиковал их труды по древней русской истории М. В. Ломоносов. И только специалисты знают, что значительный вклад в русскую историографию внес Г. Ф. Миллер своей «Историей Сибири», в отличие от Г. З. Байера, который за годы своего пребывания в России так и не выучил русского языка.

Профессору Ю. А. Васильеву удалось обнаружить в отделе редкой книги Всероссийской государственной публичной библиотеки им. М. И. Рудомино переводное издание 1809 г. работы Шлецера «Представление всеобщей истории». На основании прочитанного автор монографии приходит к глубоким заключениям о вкладе этого немецкого ученого в науку: «Шлецер оказал русской историографии «важные методологические услуги» в области разработки исторической критики. <...> Сам Шлецер не создал и не мог создать обобщающего труда, посвященного истории России. По оценке В. О. Ключевского, он не был достаточно подготовлен к научному изучению истории России. Но он имел превосходную подготовку к историко-критической работе. Все его внимание сосредоточилось на критическом изучении русской истории (см.: Васильев, 2016: 231). Исследовательский талант Шлецера раскрылся в применении сравнительного анализа летописных известий и в опыте критического сравнения текстов, а также в рационалистических приемах реконструкции первоначального текста. Намеченное Шлецером направление исследовательской деятельности нашло продолжение и развитие в российской исторической науке (см.: Свердлов, 2011: 832-833). В конце научной деятельности в Германии (1802-1809) Шлецер обобщил свои исследования древнерусского летописания и истории в пятитомной труде - знаменитом «Несторе» (Несторъ. 
Russische Annalen..., 1802-1805, 1809). За данный труд в России он был возведен Александром I в дворянское достоинство и награжден орденом Владимира IV степени».

Казалось бы, «дела давно минувших дней» и отгремевших почти 300 лет назад исторических баталий не должны быть актуальны для дня сегодняшнего, но профессор Васильев замечает: «Представляется, что официально объявленное в России в 2012 году начало зарождения российской государственности, связанное с призванием Рюрика, никак не может соответствовать ломоносовской исторической схеме. Конечно, юбилейные 1150 лет - красивая дата. Однако начало Руси, по Ломоносову, «не должно производить и начинать от времени пришествия Рурикова к новгородцам, ибо оно широко по восточно-южным берегам Варяжского моря простиралось от лет давных» (Ломоносов, 1986b: 75). Кроме того, начало отсчета русской истории от 862 года есть признание и торжество идей оппонента Ломоносова - Августа Людвига Шлецера, который утверждал, что русская история начинается от пришествия Рюрика и основания «русского царства». Шлецер заявлял, что до призвания германоязычных варягов-русов не было Русского государства, следовательно, и русской истории. Ключевое положение исторической схемы Шлецера - норманнское происхождение Рюрика и его братьев, основавших Российское государство в 862 г. Утверждается о предшествующем этому событию покорении новгородских славян, а также о последующем усилении Российского государства «покорением другого норманнского царства в Киеве в 882 г.» (Шлецер, 1809: 186, 196).

И чрезвычайно важное заключение для дня сегодняшнего: «Долгие споры норманистов и антинорманистов, продолжающиеся более двух с половиной столетий, отодвинули и заслонили собой возможное перспективное научное направление: изучение общих и особенных характеристик в зарождении десятков центров и очагов культур и цивилизаций на российских просторах. Сегодня известно, что до Киевской Руси и одновременно с ней существовали другие очаги Русий различного этнического происхождения. Современные комплексные исследования множества локальных этнокультур об этом свидетельствуют. В частности, проблема генезиса Причерноморской, Азовско-Черноморской, Донской, Неманской, Балтийской (южное и восточное побережье), Прибалтийской, Прикарпатской, Прикаспийской, Подунайской, Поморской и др. Русий не укладывается в принятые норманистские и антинорманистские доктрины. Десятилетия и даже столетия оказались потеряны для науки благодаря усилиям поколений воинственных околонаучных «thru varing» как со стороны одного, так и другого лагерей. Изучение содержания исторического процесса периода древней Руси определяется не альтернативой 
выбора одной из противоборствующих доктрин, а системным исследованием миграционных, этнокультурных, демографических, социальных и др. процессов в древней Руси в контексте общеевропейской истории» (Васильев, 2016: 43).

По мнению автора, «утверждение о том, что взгляд Ломоносова на историческую науку формировался исключительно в борьбе с норманистами и норманизмом, представляются упрощенными и односторонними, отягощенными политизированной зацикленностью на борьбе норманизма и антинорманизма по принципу разделения двух лагерей на «свой» и «чужой». Сам спор приобрел формат теорий гораздо позднее - лишь в XIX в. Варяжская проблема, не связанная у Ломоносова с началом русской истории, по сути являлась для него второстепенной: Ломоносов отстаивал не хронологическую определенность российской государственности, а древность, самобытность славян и русской культуры. История России для него - это, прежде всего, история российского народа, начавшаяся задолго до возникновения государственности. Позиция Ломоносова в отношении к «варяжскому вопросу» позднее получила созвучную интерпретацию В.О. Ключевского» (там же: 45).

Профессор Васильев отмечает, что за века противостояния «норманистов» и «антинорманистов» главный акцент делался на антинаучности и негативной деятельности «немцев», как «чужих» в русской истории, в русской науке, но автор считает, что «за внешней непримиримостью А. Л. Шлецера и М. В. Ломоносова скрывается различие исследовательских подходов: историческая критика Шлецера с ее позитивистским вектором не совпадала с историософской парадигмой Ломоносова. Однако, с позиции тезаурусного взгляда, у двух различных инструментариев есть нечто общее: и в одном случае, и в другом проявляет свое действие субъективность - в анализ исторической действительности привносится оценочный момент. За это как Шлецер, так и Ломоносов подвергались критике, особенно с позиции историзма XIX в. В отличие от прошлого, сегодня, напротив, при написании истории историку рекомендуется «использовать всю свою личность. То, как историк относится к собственному времени, каковы его внутренние чувства и переживания, какие факты оказались решающими в его собственной жизни - все эти вещи должны быть не окутаны недоверием и страхом как угроза так называемой исторической субъективности, но ценимы как важнейшее снаряжение историка, пытающегося проникнуть в тайны прошлого. Конечно, эти личные переживания не могут и не должны использоваться в качестве аргумента при изложении историком прошлого - мы хотим читать о прошлом, а не об историках, - но они абсолютно необходимы для того, чтобы он был открыт опыту прошлого. Что, в свой черед, помогает перебросить мост в 
прошлое и историку, и его читателям» (Анкерсмит, 2007: 267)».

Шлецер, предвосхищая появление такой ныне важной науки, как геополитика, подходит в своих историософских размышлениях к оценке и своеобразной «классификации» народов мира. Профессор Васильев объясняет: шлецеровская классификация народов имела троякое деление. Первую группу составляли победоносные народы: персы, татары и монголы и др. Во вторую группу определялись важные народы: египтяне, финикийцы, евреи, греки и др. В третью группу включались главные народы: ассирийцы, македонцы, испанцы, британцы. По оценке Шлецера, россияне входят именно в эту группу главных народов (см.: Васильев, 2016: 19-20, 23, 100). А вот укры (пограничные венды), по Шлецеру, как и ряд других славянских племен (в частности, в Бранденбургских землях), были практически уничтожены (там же: 193). Следует подчеркнуть, что и М. В. Ломоносов отстаивал самобытность славян, а историю России рассматривал, прежде всего, как историю российского народа. Однако, в отличие от Шлецера, хронологически для Ломоносова было неоспоримо происхождение многочисленных славянских народов в российских пределах прежде Рождества Христова, а историческая роль славян на этих землях проявилась уже в первые века нашей эры (см.: Ломоносов, 1986b: 52-55; 2007: 371, 375).

И если критерием выбора значимых народов по Шлецеру «определялась не слава их деяний, не событийная насыщенность их историй, а влияние на целое, на основные регионы мира», то можно себе представить, что XX век, признанный даже на Западе «веком России», не мог не «перевести» нас, россиян, в шлецеровскую категорию «победоносных народов». Разве нет?

Но поразительно, что русский гений Ломоносов из своего далекого исторического времени смотрел дальше Шлецера и смог провидеть популярную ныне парадигму восприятия народа историческим субъектом! Профессор Васильев утверждает: «Ломоносов стал создателем концепции отечественной истории, основным субъектом которой являлся российский народ. Постановка вопроса о народе как субъекте истории была новой для своего времени. Позднее данная идея получила научную разработку в исторической концепции В. О. Ключевского» (Васильев, 2016: 54).

Автор убежден также, что образ Ломоносова как «историка в своих одах» справедлив, поскольку в литературных произведениях Михаила Васильевича нет вымышленных героев и богов и недостоверных сюжетов, а действуют реальные исторические личности, как, например, в поэме «Петр Великий»: «Сюжет ломоносовской поэмы составили «истинные дела», то есть подлинные исторические события. Свойственный европейским классицистам пафос картезианской рассудочности заменялся 
гражданским пафосом. Впоследствии пушкинская «Полтава» стала продолжением жанра русской героической поэмы, основанной благодаря новаторскому подходу Ломоносова. В разработке ломоносовской поэмы исторические источники использовались автором исключительно с целью воспроизведения исторической правды» (там же: 54).

Особый интерес вызывает глава монографии «Живописный Ломоносов: познание возвышенного в российской истории посредством изобразительного искусства». Знаменитое мозаичное полотно «Полтавская битва», выполненное в мозаичной мастерской Михаила Васильевича по его эскизу знакома многим хотя бы по иллюстрации из учебников истории и литературы. Но, как убедительно показывает профессор Васильев, увлечение мозаичным искусством не стало для Михаила Васильевича неким отхождением от основных научных тем, напротив, оно стало одним из его историософских концептов: «К творчеству русского мыслителя, предложившего способ познания российской истории при помощи средств изобразительного искусства, восходят оригинальные разработки в познании возвышенного в истории России, созвучные современным подходам в европейском историописании. Историософская удача и заслуга Ломоносова в данном направлении, особенно актуальная для современного неопределенного (переходного) состояния гуманитарного знания, определяемого как «post-post-mo» (после постмодернизма), ассоциируется с ломоносовским подвижничеством.

И снова историософская мысль Ломоносова оказывается в русле современности - по мнению автора монографии, она соотносится с теорией возвышенного исторического опыта нидерландского профессора из Гронингенского университета Франклина Анкерсмита. По объяснению профессора Васильева, взаимодействие и непосредственный контакт с прошлым олицетворяется в образе, когда наша рука и пальцы принимают форму вазы, когда мы можем представить себе, как держим ее в руке. В данном восприятии оказался востребован мир чувств и настроений, определяющих наше отношение к прошлому. Для него не менее, а, возможно, даже более важно то, как мы чувствуем прошлое, чем то, что мы знаем о нем. В этой связи требуется осознать существенно эстетический характер исследования истории (см.: Анкерсмит, 2007: 13, 32, 108-109, 344-345, 365, 383).

Таким образом, «способ восприятия возвышенного в истории может быть раскрыт посредством механизма изучения взаимодействия современного человека (например, в роли зрителя) и предметов изобразительного искусства (живописи, скульптуры и др.), воспринимаемых в качестве исторических источников как реализованного продукта человеческой психики» (Васильев, 2016: 65). 
И если Ф. Анкерсмит демонстрирует такую возможность на примере изучения каприччо (жанра венецианской живописи) Франческо Гварди «Аркада с фонарем», наглядно показывающего современному зрителю Венецию XVIII века, то в том самом XVIII столетии М.В. Ломоносов учил своего зрителя «блуждать в древностях Российских».

Продолжая предложенные аналогии, представим, каким удивительным наглядным пособием по ветхозаветной истории и истории Святой Руси, становится любой православный храм, в котором фрески и иконы повествуют, кричат, плачут, торжествуют. И сколь важную роль в этом «историческом классе» играет священник, объясняющий своей, подчас, малограмотной пастве, то, что видит она на стенах собора. Мог ли не подумать об этом юный Ломоносов, обучающийся в Славяно-греко-латинской академии при Заиконоспасском монастыре (в Спасских школах)? А, увидев древние мозаики в соборах Киева, загорелся идеей воссоздания старинного искусства, почти уже утраченного в его историческом времени.

И не продолжением ли ломоносовской идеи о познании возвышенного в российской истории посредством изобразительного искусства стало строительство, уже совсем в другом историческом времени - метро в столице и крупных наших городах, где, благодаря древним храмовым технологиям - фреске, мозаике, скульптуре - удалось создать возвышенный образ отечественной истории, максимально приближенный к массовому зрителю? Ведь даже сегодня, уже совсем в другую историческую эпоху, станции метро продолжают молчаливый рассказ о прошлом и будут говорить, когда уже других свидетелей эпохи не останется.

Профессор Васильев, объясняя концепцию Ф. Анкерсмита, констатирует: проблема состоит не в том, чтобы найти слова для адекватного выражения нашего опыта мира. Она скорее в том, что говорить больше некому, так как опыт - это все, что у нас осталось. Если мы лишились слов, увидев или услышав великое произведение искусства, то объяснение очень простое - нет никого, кто мог бы говорить. В историческом опыте историк может расслышать «музыку прошлого». Неслучайно, что произведение искусства может эффективно пробуждать исторический опыт и служит лучшим проводником для его понимания. Мы переживаем прошлое так, как способны переживать произведение искусства. Траектория между историческим субъектом и объектом (прошлым), которая отождествляется с историческим опытом, является его территорией. Траектория между историком, гражданами современного мира, с одной стороны, и прошлым, с другой, и есть место, где рождается историческое сознание и историописание. Нельзя определить достоверно границу, где заканчиваюсь Я, исторический субъект, и начинается прошлое, объект (см.: Анкерсмит, 2007: 25, 316, 362, 427). 
К сожалению, не все идеи М. В. Ломоносова по части изучения истории через искусство были воплощены в жизнь. Например, предлагал он увековечить в мраморе и металле великих исторических личностей и наиболее значимые исторические события: «Велико есть дело смертными и преходящими трудами дать бессмертие множеству народа, соблюсти похвальных дел должную славу и, пренося минувшие деяния в потомство и в глубокую вечность, соединить тех, которых натура долготою времени разделила». Таким образом «история, повсюду распространяясь и обращаясь в руках человеческого рода, стихии строгость и грызения древности презирает» (Ломоносов, 1986b: 50).

Изучение риторики в Славяно-греко-латинской академии позволило Ломоносову освоить метод наибольшего эмоционального воздействия на окружающих, чтобы поразить воображение. В преподавании риторики ставились три задачи: учить, вызывать восхищение, поражать (захватывать) воображение. Риторические приемы, олицетворяемые с живописью словом, Ломоносов перенес в область живописных полотен и мозаичных произведений. Во время обучения в Марбургском университете Ломоносов посещал лекции на философском факультете профессора Санторока по мифологии, занятия профессора истории и элоквенции И. А. Гартмана по римскому красноречию. В период обучения в Германии Ломоносов изучил ряд пособий по риторике европейских авторов. Об этом свидетельствует наличие в его личной библиотеке изданной в 1626 г. в Кельне «Риторики церковной и светской», в 16 книгах Николя Коссена - французского филолога XVII в., а также учебного пособия Франсуа Антуана Помея - французского ученого XVII в., преподавателя риторики в Лионе, под названием «Новый «Кандидат риторики», яснее и изящнее прежнего... (учебник красноречия)» (Библиотека М. В. Ломоносова..., 2010: 108112, 138-140).

Более того, императрица Екатерина II через президента Академии художеств И. И. Бецкого передала Ломоносову распоряжение выбрать исторические сюжеты для написания по ним картин, которыми предполагалось украсить царские покои. Но, «если Екатерина II стремилась к созданию образа собственного правления в качестве «просвещенного абсолютизма», воспринимая картины в качестве предметов для эстетического украшения придворных залов, то для Ломоносова преображение реальных событий в художественные произведения имело глубокий смысл: они олицетворяли живую связь настоящего и прошлого. Он определенно видел в этом важнейшую просветительскую задачу. Именно с этой функцией связано его стремление приблизить русских художников к практическому осуществлению задачи - украсить картинами по русской истории не только дворцы правителей, но и общественные здания, оказывая 
«сие о великости благодеяния» всему российскому народу: живописные произведения «пренесут в настоящее время минувшия российския деяния показать древнюю славу праотцев наших, счастливыя и противныя обращения и случаи и тем подать наставление в делах, простирающихся к общей пользе» (Ломоносов, 1986b: 311).

Представленные Ломоносовым «Идеи для живописных картин из российской истории» сегодня стали богатейшим источником для исследования исторических взглядов самого Ломоносова, именно к этим историческим сюжетам потом еще не раз обращались русские живописцы и XIX-го, и XX-го веков. Так же, как все поколения российских историков будут обращаться к историософскому наследию великого русского ученогоэнциклопедиста Михаила Васильевича Ломоносова.

\section{СПИСОК ЛИТЕРАТУРЫ}

Автобиография Гервинуса (1893). М. : Солдатенков. 357 с.

Анкерсмит, Ф. Р. (2007) Возвышенный исторический опыт. М. : Европа. 612 с.

Библиотека М. В. Ломоносова: научное описание рукописей и печатных книг (2010) М. : Ломоносовъ. 280 с.

Васильев, Ю. А. (2015а) Начало исторической науки в Европе: тезаурус Августа Людвига Шлёцера // Знание. Понимание. Умение. № 2. С. 152-160.

Васильев, Ю.А.(2016а) Историка Иоганна Густава Дройзена как методология истории // Знание. Понимание. Умение. № 2. С. 218-226. DOI: 10.17805/zpu.2016.2.19

Васильев, Ю. А. (2006) «Кризис истории» - кризис понимания истории // Знание. Понимание. Умение. № 1. С. 35-40.

Васильев, Ю. А. (2009а) О методологических основаниях русской исторической школы: историософские аспекты. Часть I // Знание. Понимание. Умение. № 1. С. 49-58.

Васильев, Ю. А. (2009b) О методологических основаниях русской исторической школы: историософские аспекты. Часть II // Знание. Понимание. Умение. № 2. С. 78-88.

Васильев, Ю. А. (2010а) Феномен «Ecole Russe»: теория истории Н. И. Кареева (начало) // Знание. Понимание. Умение. № 2. С. 124-128.

Васильев, Ю.А. (2010b) Феномен «Ecole Russe»: теория истории Н. И. Кареева (окончание) // Знание. Понимание. Умение. №3. С. 121-134.

Васильев, Ю.А. (2011а) Идентичность русского народа в исторической концепции В. О. Ключевского // Власть. № 7. С. 35-39.

Васильев, Ю. А. (2011b) Феномен «Ecole Russe»: критика Н. И. Кареева // Знание. Понимание. Умение. № 3. С. 121-127.

Васильев, Ю. А. (2012а) Взгляд на эпометаморфоз сквозь призму 
всемирно-исторической точки зрения // Век глобализации. № 1. С. 46-57.

Васильев, Ю.А. (2012b) Феномен «Ecole russe»: историология Н. И. Кареева // Знание. Понимание. Умение. № 1. С. 72-81.

Васильев, Ю. А. (2014а) Идеи М. В. Ломоносова в русской исторической школе // Знание. Понимание. Умение. № 2. С. 141-148.

Васильев, Ю. А. (2014b) Тайны «Могикана» (К 100-летию со дня рождения Ю. В. Андропова) : монография. М.: Изд-во Моск. гуманит. ун-та. $200 \mathrm{c}$.

Васильев, Ю. А. (2015b) От Bildung к Wissenschaft: гейдельбергская историческая школа // Власть. № 5. С. 179-183.

Васильев, Ю. А. (2016b) Как преодолеть разрыв между историческим знанием и общественным сознанием? (опыт русской исторической школы) // Власть. № 2. С. 96-101.

Васильев, Ю. А. (2016с) М. В. Ломоносов в русской исторической школе : монография. М.: Из-во Моск. гуманит. ун-та. 168 с.

Васильев, Ю. А.; Васильева, М. Ю. (2014) Влияние идей Христиана Вольфа на мировоззрение М. В. Ломоносова // Власть. № 3. С. 121-125.

Васильева, М. Ю. (2015а) Проблема свободы воли в философии И. Канта // Вестник Московского университета. Серия 7 : Философия. № 6. С. 27-31.

Васильева, М. Ю. (2015b) Проблема свободы воли в трансцендентальной философии И. Канта // Власть. № 7. С. 96-101.

Васильева, М. Ю. (2013) Учение о мире в диссертации И. Канта «О форме и принципах чувственно воспринимаемого и интеллигибельного мира» // Философские науки. № 10. С. 106-114.

Дройзен, И. Г. (2004) Историка. СПб. : Владимир Даль ; Фонд «Университет». 584 с.

Ломоносов, М. В. (1986а) Избранные произведения: в 2 т. Т. 1. Естественные науки и философия. М. : Наука. 536 с.

Ломоносов, М. В. (1986b) Избранные произведения: в 2 т. Т. 2. История. Филология. Поэзия. М. : Наука. 496 с.

Ломоносов, М. В. (2007) Записки по русской истории. М. : Эксмо. 736 с.

M.В. Ломоносов: pro et contra (Личность и творчество М.В. Ломоносова в оценках русских мыслителей и исследователей). (2011) СПб. : Русская христианская гуманитарная академия. 1120 с.

Михаил Васильевич Ломоносов. Переписка. 1737-1765 (2010) М. : Ломоносовъ. 512 с.

Михаил Ломоносов глазами современников (2011)/ Документы. Письма. Записки. Статьи. Эпитафии и панегирики. Надписи. М. : Ломоносовъ. $536 \mathrm{c}$.

Несторъ. Russische Annalen in ihrer Slavonischen GrundSprache: verglichen, von SchreibFelern und Interpolationen möglich gereinigt, erklärt, 
und übersetzt, von August Ludwig von Schlözer, Hofrath und Professor der StatsWissenschaften in Göttingen, des Kaiserl[ichen] Russischen Ordens des heil[igen] Wladimirs 4ter Klasse Ritter. Göttingen: bei Heinrich Dieterich, 1802-1805, Teile 1-4; von Vandenhoek und Ruprecht, 1809, Teil 5.

Свердлов, М.Б. (2011) М.В. Ломоносов и становление исторической науки в России. СПб. : Нестор-История. 916 с.

Христиан Вольф и философия в России (2001) СПб. : Русский христианский гуманитарный институт. 400 с.

Шлёцер, А.Л. (1809) Представление всеобщей истории. Спб. : Святейший Синод. 227 с.

Дата поступления: 12.04.2017 г.

Жукова Ольга Германовна - кандидат исторических наук, доцент кафедры истории Московского гуманитарного университета, член Союза писателей России, член Союза журналистов Москвы. Адрес: 111395, Россия, г. Москва, ул. Юности, д. 5, корп. 3. Тел.: +7 (499) 374-55-81. Эл. адрес: historymosgy@mail.ru

Zhukova Olga Germanovna, Candidate of History, Associate Professor Department of History, Moscow University for the Humanities; Member, the Writers' Union of Russia; Member, the Journalists' Union of Moscow. Postal address: 5, Bldg. 3, Yunosti St., Moscow, Russian Federation 111395. Tel: + 7 (499) 374-55-81. E-mail: historymosgy@mail.ru

\section{Для циитирования:}

Жукова О. Г. Ломоносовский порыв: история как философия, искусство, поэзия [Электронный ресурс] // Научные труды Московского гуманитарного университета. 2017, № 3. URL: http://journals.mosgu.ru/trudy/article/view/501 (дата обращения: дд.мм. гг.). DOI: $10.17805 /$ trudy.2017.3.7 